\title{
HEPATITIS C VIRUS ANTIBODY STATUS, SOCIODEMOGRAPHIC CHARACTERISTICS, AND RISK BEHAVIOUR AMONG INJECTING DRUG USERS IN CROATIA
}

\author{
Tatjana Vilibić Čavlek1,2, Jelena Marić1, Ljiljana Katičić1, Branko Kolarić3,4 \\ ${ }^{1}$ Department of Virology, Croatian National Institute of Public Health, Zagreb, Croatia

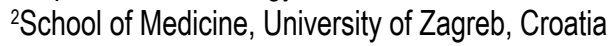 \\ ${ }^{3}$ Zagreb County Institute of Public Health, Velika Gorica, Croatia \\ ${ }^{4}$ School of Medicine, University of Rijeka, Croatia
}

\begin{abstract}
SUMMARY
The study was conducted among 76 injecting drug users (IDU) from seven Croatian cities during a three-year period (2005-2007). Each participant completed a questionnaire on sociodemographic characteristics and potential risk factors for hepatitis $\mathrm{C}$ virurs (HCV) infection followed by anti-HCV and anti-HIV antibody testing. The mean patient age was 30 . The majority of patients $(69.8 \%)$ reported more than one potential exposure to HCV: $97.1 \%$ had shared injecting equipment, $75 \%$ reported risk sexual behaviour, and $56.3 \%$ reported a history of travelling abroad. The overall HCV seroprevalence was $51.3 \%(95 \% \mathrm{Cl}=40-63 \%)$. HCV seroprevalence increased with increasing number of risk behaviours $(\mathrm{p}=0.026)$. Needle sharing frequency was the most important risk factor for hepatitis $\mathrm{C}$. The HCV seroprevalence rate ranged from $27.3 \%$ in IDUs who answered that they shared needles occasionally to $100 \%$ in IDUs who always shared needles $(p<0.001)$. No other risk factors (age, gender, educational level, marital and employment status, history of travelling abroad and sexual risk behaviour) were associated with HCV seropositivity.
\end{abstract}

Key words: hepatitis C, IDU, seroprevalence, risk factors

Address for correspondence: T. V. Čavlek, Croatian National Institute of Public Health, Department of Virology, Rockefellerova 12, 10000 Zagreb, Croatia. E-mail: tatjana.vilibic-cavlek@hzjz.hr

\section{INTRODUCTION}

Hepatitis C virus (HCV) infection represents a global health problem. The World Health Organization estimates that 170-200 million people worldwide are chronically infected with HCV (1). Seroprevalence of HCV varies in different risk groups such as recipients of previously unscreened blood or blood products (before 1992), hemophiliacs, patients in hemodialysis centers and injecting drug users (IDUs). The prevalence of anti-HCV is highest in IDUs and hemophilia patients (up to $95 \%$ ) (2-8) and highly variable in hemodialysis patients $(10-90 \%)(9,10)$. In addition, HCV coinfection with human immunodeficiency virus (HIV) is common among IDUs, who acquire both viruses from injecting $(11,12)$. IDUs may also be at sexual risk of $\mathrm{HCV}$ infections, as they exhibit risky sexual behaviour (multiple sexual partners, IDU partners and commercial sex activity) (14). Several studies have found evidence for the sexual transmission of HCV (14-16).

This study analyzed the seroprevalence, sociodemographic characteristics as well as injecting and sexual risk factors associated with $\mathrm{HCV}$ infection among IDUs in Croatia.

\section{MATERIALS AND METHODS}

\section{Population}

This cross section study was conducted among 76 injecting drug users from seven Croatian cities during a three-year period (2005-2007). The respondents were recruited among clients of voluntary counselling and testing services. After obtaining informed consent, each participant completed a questionnaire followed by venipuncture for anti-HCV and anti-HIV antibody testing. The data obtained included sociodemographic information (age, gender, educational level, marital and employment status), history of travelling abroad, and their injecting and sexual risk behaviours. Questions relating to drug use included whether and how often the respondents shared injecting equipment. Sexual risk variables included: number of sexual partners in the preceding year, being a man who has sex with men (MSM), being a sex worker (SW) or a client of SW, and having a history of sexually transmitted infections (STIs). All participants received educational material and counselling on HIV and hepatitis C (17). 


\section{Serologic Testing}

Serum samples were tested for anti-HCV antibodies using a third generation enzyme-linked immunosorbent assay (Ortho HCV 3.0. ELISA Test, Ortho-Clinical Diagnostics, Raritan, NJ). Initially reactive samples were retested in duplicate and positive samples were determined by the manufacturer cut-off value (average of 3 negative samples \pm 0.330 ). Anti-HIV antibodies were detected using fourth generation enzyme-linked fluorescent assay (Mini Vidas HIV Duo Quick; BioMerieux, Marcy l'Etoile, France).

\section{Statistical Analysis}

Mann-Whitney U and Fisher's exact test were used to compare differences between groups. For statistical analysis, SPSS version 17.01 (SPSS, Inc., Chichago, IL) software was used. $\mathrm{P}<0.05$ was considered to be statistically significant.

Table 1. Anti-HCV prevalence by sociodemographic characteristic and potential risk factors

\begin{tabular}{|c|c|c|c|}
\hline Characteristic & $\begin{array}{c}\text { No. of } \\
\text { participants } \\
(\%)\end{array}$ & $\begin{array}{c}\text { Anti-HCV } \\
\text { positive } \\
\mathrm{N}(\%)\end{array}$ & $p$ value \\
\hline Sex & & & 0.256 \\
\hline Male & $69(90.8)$ & $37(53.6)$ & \\
\hline Female & $7(9.2)$ & $2(28.6)$ & \\
\hline Age groups & & & 0.133 \\
\hline 20-29 years & $43(56.6)$ & $20(46.5)$ & \\
\hline $30-39$ years & $26(34.2)$ & $12(46.2)$ & \\
\hline $40-49$ years & $7(9.2)$ & $7(100.0)$ & \\
\hline Educational level & & & 0.051 \\
\hline$<$ Primary school & $8(10.5)$ & $7(87.5 \%)$ & \\
\hline High school & $56(73.7)$ & $26(46.4)$ & \\
\hline$>$ High school & $5(6.6)$ & $2(40.0)$ & \\
\hline Missing & $7(9.2)$ & $4(57.1)$ & \\
\hline Marital status & & & 0.268 \\
\hline Married & $10(13.1)$ & $8(80.0)$ & \\
\hline Single & $41(54.0)$ & $21(51.2)$ & \\
\hline Steady sexual partner & $12(15.8)$ & $5(41.7)$ & \\
\hline Separated/divorced & $9(11.8)$ & $3(33.3)$ & \\
\hline Missing & $4(5.3)$ & $2(50.0)$ & \\
\hline Employment status & & & 0.435 \\
\hline Employed & $19(25.0)$ & $8(42.1)$ & \\
\hline Unemployed & $56(73.7)$ & $31(55.3)$ & \\
\hline Missing & $1(1.3)$ & - & \\
\hline History of travelling abroad & & & 0.838 \\
\hline Yes & $28(36.9)$ & $15(53.6)$ & \\
\hline No & $45(59.2)$ & $24(53.3)$ & \\
\hline Missing & $3(3.9)$ & - & \\
\hline Sharing needles/syringes & & & - \\
\hline Yes & $66(86.9)$ & $38(57.6)$ & \\
\hline No & $2(2.6)$ & $0(0)$ & \\
\hline Missing & $8(10.5)$ & $1(12.5)$ & \\
\hline
\end{tabular}

\begin{tabular}{|l|c|c|c|}
\hline Needle share frequency & & & $<0.001$ \\
\hline Never & $2(2.9)$ & $0(0)$ & \\
\hline Occasionally & $22(32.4)$ & $6(27.3)$ & \\
\hline Frequently & $39(57.4)$ & $27(69.2)$ & \\
\hline Always & $5(7.4)$ & $5(100.0)$ & \\
\hline Risk sexual behaviour & & & 0.591 \\
\hline Yes & $57(75)$ & $31(54.4)$ & \\
\hline No & $19(25)$ & $8(42.1)$ & \\
\hline Number of sexual partners & & & 0.108 \\
\hline $0-9$ & $66(86.9)$ & $37(56.0)$ & \\
\hline $10-19$ & $6(7.9)$ & $2(33.3)$ & \\
\hline$\geq 20$ & $2(2.6)$ & $0(0)$ & \\
\hline Missing & $2(2.6)$ & - & \\
\hline History of STls & & & 0.286 \\
\hline Yes & $23(30.3)$ & $19(82.6)$ & \\
\hline No & $53(69.7)$ & $30(56.6)$ & \\
\hline Number of risk factors & & & \\
\hline 1 & $23(30.2)$ & $9(39.1)$ & \\
\hline 2 & $34(44.7)$ & $15(44.1)$ & \\
\hline 3 & $12(15.8)$ & $10(83.8)$ & \\
\hline 4 & $5(6.6)$ & $3(60.0)$ & \\
\hline 5 & $2(100.0)$ & $2(2.6)$ & 0.026 \\
\hline
\end{tabular}

*Having multiple sexual partners, being a man who have sex with men, being a commercial sex workers (SW) or a client of SW

\section{RESULTS}

\section{Sociodemographic Characteristics and Risk Behavi- ours}

Sociodemographic characteristics and risk behaviours of study participants are shown in Table 1.

Patient age ranged from 21 to 48 years with the mean \pm SD of $30 \pm 6$ years and a median age of 28 years. Out of the 76 participants, $69(90.8 \%)$ were males. About one half of participants (54\%) were single, $80.3 \%$ have graduated high school or had higher education and $73.7 \%$ were unemployed. All participants denied a history of blood transfusion while $36.9 \%$ reported a history of travelling abroad. A majority of patients (69.8\%) reported more than one potential exposure to HCV. Eighty-six point nine percent of participants answered that they share injecting equipment, and $75 \%$ reported risk sexual behaviour: having multiple sexual partners $(66.2 \%)$, being a MSM $(11.8 \%)$, being a SW or a client of SW (15.8\% and $22.4 \%$, respectively) and having STIs (30.3\%).

\section{HCV Seroprevalence}

The overall HCV seroprevalence was $51.3 \%(95 \% \mathrm{CI}=40$ $63 \%)$. HCV prevalence was higher in men $(53.6 \% ; 95 \%$ $\mathrm{CI}=42-65 \%)$ than in women $(28.6 \% ; 95 \% \mathrm{CI}=0-62 \%)$, although this difference was not significant $(\mathrm{p}=0.256)$. In participants 40 years or older, HCV seropositivity was $100 \%$ compared with $46 \%$ in younger participants. The HCV seroprevalence rate did 
not vary significantly between age groups $(\mathrm{p}=0.133)$. Neither marital $(\mathrm{p}=0.268)$ nor employment status $(\mathrm{p}=0.435)$ was associated with HCV seroprevalence. Participants who reported risky sexual behaviuor showed a somewhat higher seroprevalence rate than those who did not ( $54.4 \%$ versus $42.1 \%$ ), but this difference was not significant $(p=0.591)$. There was no association of HCV seroprevalence with the number of sexual partners $(\mathrm{p}=0.108)$ or a history of STIs $(p=0.286)$. Needle sharing frequency was the most important risk factor significantly associated with HCV seropositivity. The seroprevalence rate increased from $27.3 \%$ in IDUs who answered that they shared needles occasionally to $100 \%$ in IDUs who always shared needles $(\mathrm{p}<0.001)$. The number of risk factors was also associated with HCV seropositivity $(\mathrm{p}=0.026)$ (Table 1). None of the participant was anti-HIV positive.

\section{DISCUSSION}

After the introduction of HCV antibody screening of the blood supply, intravenous drug use has become the most important mode of HCV transmission. In Europe, seroprevalence of hepatitis C in IDUs varies from $10-40 \%$ in Hungary and the Czech Republic, to $40-70 \%$ in Italy, Germany, France, the Netherlands and Ukraine, reaching up to $80-90 \%$ in Denmark, Finland and Spain (12).

There are very limited data on the seroprevalence and risk factors for HCV infection among Croatian IDUs. IDUs constitute a marginalized and hard-to-rich population. The high proportion of anti-HCV antibodies in this study (51.3\%) indicates that HCV infection is common in this risk group in Croatia. Patients with positive results were referred to treatment centres for infectious diseases (18).

There is no concordance between seroprevalence studies as to whether gender represents a risk factor for $\mathrm{HCV}$ transmission. While some studies reported a higher prevalence of hepatitis $\mathrm{C}$ in males $(3,4,19)$, other reported no gender difference in HCV rates $(13,20)$. Our results showed a higher seroprevalence of hepatitis $\mathrm{C}$ in males (53.6\%) compared to females (28.6\%). This difference was not significant $(p=0.256)$, but there were only seven women in this study. Men are probably more prone to experiment with drugs.

Lower educational level is believed to be an important factor for higher prevalence of hepatitis C $(19,21)$. In this study, antiHCV positivity was $87.5 \%$ in IDUs who had not graduated high school compared with $45.9 \%$ of IDUs who had graduated high school or had higher education but this difference did not reach statistical significance $(p=0.051)$. Age $(p=0.133)$, marital status $(\mathrm{p}=0.268)$ and employment status $(\mathrm{p}=0.435)$ were not associated with HCV seropositivity.

Like the majority of similar studies worldwide $(22,23)$, we demonstrated association between frequency of sharing needles and syringes and HCV seroprevalence. HCV seropositivity was the highest among IDUs who had always shared needles (100\%) compared to those who shared needles frequently $(69.2 \%)$ and those who shared needles occasionally $(27.3 \%$; $<<0.001)$. Croatia implemented harm reduction programmes, including needles and syringes exchange which is mostly performed by non-governmental organizations (18).

Some studies have shown that co-infection with HIV significantly increases the probability of $\mathrm{HCV}$ infection among IDUs (13). We documented no HIV-HCV co-infection in this study.
In this study, the majority of participants $(69.8 \%)$ reported multiple risk behaviours. It is possible that risk factors other than injection drug use might have been responsible for $\mathrm{HCV}$ transmission in IDUs. The results of the recent study conducted in Croatia showed that high risk sexual behaviuor is associated with an increased risk of HCV infection (16). We evaluated sexual risk factors for their association with anti-HCV prevalence in this group. Risk sexual behaviour was reported by $75 \%$ participants. Although not significant $(p=0.591)$, a higher HCV seroprevalence rate demonstrated in IDUs who reported risk sexual behaviour $(54.4 \%)$ than in those who did not $(42.1 \%)$ indicates that interaction of risk sexual behaviour with injecting risk behaviour cannot be disregarded.

Another possible risk factor for $\mathrm{HCV}$ acquisition may be a residence or travel in a region in which $\mathrm{HCV}$ infection is endemic (24). A study conducted among young IDUs in San Francisco showed significantly higher prevalence of HCV in IDUs who had travelled compared to those who had not (25). In this study, we found no difference in HCV seropositivity between participants with a history of travelling abroad and those who denied travelling $(\mathrm{p}=0.838)$.

The main limitation of this survey is possible introduction of selection bias. The respondents were clients of voluntary counselling and testing services who stated injecting drugs. The population represented by our sample cannot be identified. Study results are, therefore, only informative and cannot be generalized the broader population. Furthermore, this was a very small sample. IDUs represent a hard-to-reach population, which limits the number of individuals who are willing to participate in a study. Average annual number of registered treated IDUs during the study period was 7,700 (data from the Croatian National Registry of Treated Psychoactive Drug Addicts) and the estimated number of IDUs in Croatia is 15,444 (range 7,876-42,896) (18).

Despite this limitation, our results showed that drug injecting practices are strongly associated with hepatitis $\mathrm{C}$. The frequency of sharing injection equipment was the most important factor in $\mathrm{HCV}$ transmission among Croatian IDUs. IDUs still represents a high-risk group with multiple risk factors for hepatitis $\mathrm{C}$ transmission. They not only have high HCV prevalence but also constitute a reservoir of $\mathrm{HCV}$ in the community. For these reasons, counselling and testing for HCV must be available for clients of programs for prevention and treatment of substance abuse. On the other hand, needle and syringes exchange programmes should be strengthen in order to decrease harm and burden of blood-borne viral diseases among people who inject drugs.

\section{Acknowledgements}

Source of funding for this research was a donation of The Global Fund to fight AIDS, Tuberculosis and Malaria to the Republic of Croatia.

The study was approved by the Ethic Committee of the Croatian National Institute of Public Health. The authors thank Snjezana Artl for technical assistance.

\section{REFERENCES}

1. Global surveillance and control of hepatitis C. Report of a WHO Consultation organized in collaboration with the Viral Hepatitis Prevention Board, Antwerp, Belgium. J Viral Hepat. 1999 Jan;6(1):35-47. 
2. Thorpe LE, Ouellet LJ, Hershow R, Bailey SL, Williams IT, Williamson $\mathrm{J}$, et al. Risk of hepatitis $\mathrm{C}$ virus infection among young adult injection drug users who share injection equipment. Am J Epidemiol. 2002 Apr $1 ; 155(7): 645-53$.

3. Merkinaite S, Lazarus JV, Gore C. Addressing HCV infection in Europe: reported, estimated and undiagnosed cases. Cent Eur J Public Health. 2008 Sep;16(3):106-10.

4. Kyrychenko PD. Seroprevalence of HIV and HCV markers among injection drug users seeking medical care. In: 15th International conference on AIDS; 2004 Jul 11-16; Bangkok, Thailand. Bangkok: 2004; abstract no. MoPeC3526.

5. Vassilev ZP, Hagan H, Lyubenova A, Tomov N, Vasilev G, Krasteva D, et al. Needle exchange use, sexual risk behaviour, and the prevalence of $\mathrm{HIV}$, hepatitis B virus, and hepatitis $\mathrm{C}$ virus infections among Bulgarian injection drug users. Int J STD AIDS. 2006 Sep;17(9):621-6.

6. Smyth BP, Barry J, Keenan E. Irish injecting drug users and hepatitis C: the importance of the social context of injecting. Int J Epidemiol. 2005 Feb;34(1):166-72.

7. Hickman M, Hope V, Brady T, Madden P, Jones S, Honor S, et al. Hepatitis $\mathrm{C}$ virus (HCV) prevalence, and injecting risk behaviour in multiple sites in England in 2004. J Viral Hepat. 2007 Sep;14(9):645-52.

8. Vicente J, Wiessing L; EMCDDA, national focal points and expert networks. European Monitoring Centre for Drugs and Drug Addiction annual report 2007: positive assessment of HIV in IDUs though hepatitis C still very high. Euro Surveill. 2007 Nov 22;12(11):E071122.6.

9. Jadoul M, Poignet JL, Geddes C, Locatelli F, Medin C, Krajewska M, et al; HCV Collaborative Group. The changing epidemiology of hepatitis $\mathrm{C}$ virus (HCV) infection in haemodialysis: European multicentre study. Nephrol Dial Transplant. 2004 Apr;19(4):904-9.

10. Olut AI, Ozsakarya F, Dilek M. Seroprevalence of hepatitis C virus infection and evaluation of serum aminotransferase levels among haemodialysis patients in Izmir, Turkey. J Int Med Res. 2005 Nov-Dec;33(6):641-6.

11. World Hepatitis Awareness Day, 2007. HCV infection in Europe. Vilnius: Eurasian Harm Reduction Network; 2007.

12. Wiessing L, Guarita B, Giraudon I, Brummer-Korvenkontio H, Salminen $\mathrm{M}$, Cowan SA. European monitoring of notifications of hepatitis $\mathrm{C}$ virus infection in the general population and among injecting drug users (IDUs) - the need to improve quality and comparability. Euro Surveill. 2008 May 22;13(21):pii 18884

13. Xia X, Luo J, Bai J, Yu R. Epidemiology of hepatitis C virus infection among injection drug users in China: systematic review and meta-analysis. Public Health. 2008 Oct;122(10):990-1003.
14. Thomas DL, Zenilman JM, Alter HJ, Shih JW, Galai N, Carella AV, et al. Sexual transmission of hepatitis $\mathrm{C}$ virus among patients attending sexually transmitted diseases clinics in Baltimore: an analysis of 309 sex partnerships. J Infect Dis. 1995 Apr;171(4):768-75.

15. Wejstål R. Sexual transmission of hepatitis C virus. J Hepatol. 1999;31 Suppl 1:92-5.

16. Cavlek TV, Margan IG, Lepej SZ, Kolaric B, Vince A. Seroprevalence, risk factors, and hepatitis $\mathrm{C}$ virus genotypes in groups with high-risk sexual behavior in Croatia. J Med Virol. 2009 Aug;81(8):1348-53

17. Gjenero-Margan I, Kolarić B. Epidemiology of HIV infection and AIDS in Croatia - an overview. Coll Antropol. 2006 Dec;30 Suppl 2:11-6.

18. Kolarić B, Stajduhar D, Gajnik D, Rukavina T, Wiessing L. Seroprevalence of blood-borne infections and population sizes estimates in a population of injecting drug users in Croatia. Cent Eur J Public Health. 2010 Jun;18(2):104-9.

19. Jittiwutikarn J, Thongsawat S, Suriyanon V, Maneekarn N, Celentano $\mathrm{D}$, Razak $\mathrm{MH}$, et al. Hepatitis $\mathrm{C}$ infection among drug users in northern Thailand. Am J Trop Med Hyg. 2006 Jun;74(6):1111-6.

20. Garten RJ, Lai S, Zhang J, Liu W, Chen J, Vlahov D, et al. Rapid transmission of hepatitis $\mathrm{C}$ virus among young injecting heroin users in Southern China. Int J Epidemiol. 2004 Feb;33(1):182-8.

21. Hershow RC, Kalish LA, Sha B, Till M, Cohen M. Hepatitis C virus infection in Chicago women with or at risk for HIV infection: evidence for sexual transmission. Sex Transm Dis. 1998 Nov;25(10):527-32.

22. Barros H, Ramos E, Lucas R. A survey of HIV and HCV among female prison inmates in Portugal. Cent Eur J Public Health. 2008 Sep;16(3):11620 .

23. Medić A, Dželalija B, Sonicki Z, Zekanović D. Characteristics of hepatitis $\mathrm{C}$ infection in injecting drug users in Zadar County, Croatia. Coll Antropol. 2008 Sep;32(3):697-702.

24. Wong T, Lee SS. Hepatitis C: a review for primary care physicians. CMAJ 2006 Feb 28;174(5):649-59.

25. Hahn JA, Page-Shafer K, Ford J, Paciorek A, Lum PJ. Traveling young injection drug users at high risk for acquisition and transmission of viral infections. Drug Alcohol Depend. 2008 Jan 11;93(1-2):43-50.

Received December 18, 2009 Accepted in revised form October 4, 2010 